\title{
Microbial dynamics in coastal waters of East Antarctica: plankton production and respiration
}

\author{
Carol Robinson $^{1,4, *, * *}$, Stephen D. Archer ${ }^{2,3,4, *}$, Peter J. le B. Williams ${ }^{1}$ \\ ${ }^{1}$ University of Wales Bangor, School of Ocean Sciences, Menai Bridge, Anglesey LL59 5EY, United Kingdom \\ ${ }^{2}$ British Antarctic Survey, High Cross, Madingley Road, Cambridge CB3 0ET, United Kingdom \\ ${ }^{3}$ Department of Biology, University of Southampton, Medical and Biological Sciences Building, \\ Bassett Crescent East, Southampton SO16 7PX, United Kingdom \\ ${ }^{4}$ In collaboration with the Australian Antarctic Division, Channel Highway, Kingston, Tasmania 7050, Australia
}

\begin{abstract}
The rates of plankton community production and respiration were determined from in vitro changes in dissolved inorganic carbon and dissolved oxygen and the incorporation of $\mathrm{NaH}^{14} \mathrm{CO}_{3}$ at a coastal site in East Antarctica between 16 December 1993 and 12 February 1994. The breakout of seasonal fast ice was associated with a succession of dominant phytoplankton from Cryptomonas to Phaeocystis to a diatom assemblage. Gross production reached $33 \mathrm{mmol} \mathrm{C} \mathrm{m}{ }^{-3} \mathrm{~d}^{-1}$ and ${ }^{14} \mathrm{C}$ incorporation peaked at $24 \mathrm{mmol} \mathrm{C} \mathrm{m} \mathrm{C}^{-3} \mathrm{~d}^{-1}$ on 23 January 1994, at the time of the chlorophyll a maximum (22 mg chl $\mathrm{a} \mathrm{m}^{-3}$ ). Dark community respiration reached its maximum (13 mmol C m$\left.{ }^{-3} \mathrm{~d}^{-1}\right) 4$ d later. Photosynthetic rates calculated from ${ }^{14} \mathrm{C}$ incorporation were significantly lower ( 17 to $59 \%$ ) than rates of gross production. The derivation of plankton processes from changes in both dissolved oxygen and dissolved inorganic carbon allowed the direct measurement of photosynthetic and respiratory quotients. A linear regression of all data gave a photosynthetic quotient of $1.33 \pm 0.23$ and a respiratory quotient of $0.88 \pm$ 0.14 . Concurrent determinations of bacterial, heterotrophic dinoflagellate, nanoflagellate and ciliate respiration could account for 15 to $58 \%$ of measured dark community respiration. This study has improved the sparse data set of plankton respiration measurements, confirmed that heterotrophic respiration is a significant process in the carbon flux of coastal Antarctic waters and achieved a first apportionment of community respiration to the major microbial groups in this region.
\end{abstract}

KEY WORDS: Photosynthesis - Respiration · Plankton · Antarctic

\section{INTRODUCTION}

The biological conversion of dissolved inorganic carbon (DIC) to particulate inorganic and dissolved and particulate organic carbon in the euphotic zone of the ocean has a major influence on atmospheric $\mathrm{CO}_{2}$ concentrations and the amount of organic carbon available to higher marine organisms. The accurate determination of this DIC conversion is therefore of critical importance and is equal to the excess of DIC consumed during photosynthesis over that produced during plankton community respiration. Estimates of plankton photosynthesis derived from the incorporation of ${ }^{14} \mathrm{C}$ are now routine; however, concurrent measurements

- Present address: Plymouth Marine Laboratory, Prospect Place, West Hoe, Plymouth PL1 3DH, United Kingdom

・E-mail: carol.robinson@pml.ac.uk of community respiration are often lacking. The development of the coulometric titration system for the precise measurement of DIC (Johnson et al. 1987, Robinson \& Williams 1991) means that microbiologically induced changes in DIC concentration can now be directly measured and plankton respiration can be determined concurrently with plankton photosynthesis.

Plankton processes in the Southern Ocean are currently receiving much scientific attention, due in part to the recognition that this region may respond dramatically to global change (Codispoti et al. 1991). Because of the short duration of oceanographic research cruises it is not possible to characterise and explain changes in oceanic biogeochemical and ecological variables over longer time periods or changes due to episodic environmental events. Seasonal and annual time series studies provide invaluable data for 
calibration and validation of biological and biogeochemical models, and if continued over the longer term (5 to $10+y r)$, may detect changes in the ecological and chemical state of the ocean brought about by global climate change (JGOFS 1990).

The present study formed part of a co-ordinated programme which aimed to measure the temporal progression of microbial processes in Antarctic coastal waters. Concurrent studies within the programme included herbivory by heterotrophic dinoflagellates (Archer et al. 1996a), bacterial production and nanoflagellate bacterivory (Leakey et al, 1996), the microbial ecology of sea ice (Archer et al. 1996b) and ciliate herbivory (J. Grey \& R.J.G. Leakey unpubl.). The combined data of the co-ordinated programme allows the routes of carbon flow through the microbial food web to be examined (Robinson et al. 1996, Leakey et al. unpubl.).

This paper presents estimates of plankton photosynthesis and respiration derived from 3 independent methods: changes in DIC and dissolved oxygen concentrations and the incorporation of ${ }^{14} \mathrm{C}$-labelled bicarbonate at 1 site over a 60 d period.

This has enabled the determination of the temporal change in both autotrophic and heterotrophic microbial processes and the first direct measurements of plankton respiration, production/respiration ( $P / R)$ ratios and photosynthetic and respiratory quotients in this region.

Due to an incomplete understanding of intracellular carbon flow within the algal cell, the scientific community is still without consensus as to whether, and under what controlling conditions, the ${ }^{14} \mathrm{C}$ technique measures net or gross photosynthesis (Ryther 1956, Steemann Nielsen \& Hansen 1959). Williams et al. (1996) highlighted the need to accrue a database of ${ }^{14} \mathrm{C}$ and DIC rate comparisons in order to establish the scale of the problem of interpreting ${ }^{14} \mathrm{C}$ field data. Although not a primary aim of this study, a data set of concurrent ${ }^{14} \mathrm{C}$ and $\mathrm{DIC}$ rate measurements was obtained.

Finally, and to our knowledge uniquely, concurrent measurements of bacterial, ciliate, nanoflagellate and heterotrophic dinoflagellate biomass and activity have been used to apportion community respiration to these major trophic groups.

\section{METHODS}

This study was undertaken at a coastal location in the vicinity of the Australian Antarctic station of Davis $\left(68^{\circ} 35^{\prime} \mathrm{S}, 77^{\circ} 58^{\prime} \mathrm{E}\right)$ during the austral summer of 1993-1994

Sampling. The study site O'Gorman Rocks, Antarctica (Fig. 1, $1 \mathrm{~km}$ offshore, $22 \mathrm{~m}$ depth), was sampled at approximately weekly intervals between 9 December 1993 and 12 February 1994 for determination of the depth distribution of temperature, salinity, dissolved oxygen and DIC. At approximately twice weekly intervals, water samples were collected from a depth of $5 \mathrm{~m}$ at O'Gorman Rocks for estimation of gross and net community production and dark community respiration from in vitro changes in dissolved oxygen and carbon dioxide, plankton photosynthesis from the incorporation of $\mathrm{NaH}^{14} \mathrm{CO}_{3}$, and chlorophyll a concentration.

CTD measurements. Conductivity, temperature and depth were recorded with a handheld CTD (Platypus Engineering, Tasmania) at weekly intervals at $\mathrm{O}^{\prime}$ Gorman Rocks.

Dissolved oxygen and inorganic carbon measurements. Water was siphoned from the acid-washed Goflo bottle into borosilicate glass bottles using silicon tubing. Dissolved oxygen concentration was measured with an automated whole bottle Winkler titration system using a photometric endpoint (Williams \& Jenkinson 1982). Oxygen saturation was calculated using the equations for the solubility of oxygen in seawater of Benson \& Krause (1984). DIC was measured by automated coulometric titration (Robinson \& Williams 1991, DOE 1994). Analysis of seawater DIC reference materials certified at $1984.05 \pm 0.57$ (A.G. Dickson) throughout the fieldwork (mean $=1985.81 \pm 2.35 ; \mathrm{n}=$ 9) provided quality assessment of the precision and accuracy of the DIC measurements.

Measurement of gross production (GP), net community production (NCP) and dark community respiration (DCR). Bulk water samples $\left(60 \mathrm{dm}^{3}\right)$ were collected in an acid-washed opaque polypropylene aspirator using an acid-washed $5 \mathrm{dm}^{3}$ Goflo sampling bottle through a dedicated hole in the ice, or deployed from the side of a boat once the ice moved away. Sampling took place during hours of least sunlight (approx. 23:00 h), and precautions were taken to minimise light shocking of the sample during sample collection and manipulation. Water was siphoned from the $60 \mathrm{dm}^{3}$ opaque aspirator into borosilicate glass bottles through darkened silicon tubing, overflowing each sample bottle by 4 times its volume. Four $150 \mathrm{~cm}^{3}$ dissolved oxygen sample bottles and three $250 \mathrm{~cm}^{3}$ DIC sample bottles were fixed immediately for measurement of zero time concentrations. DIC samples were fixed with a saturated mercuric chloride solution $\left(250 \mathrm{~mm}^{3}\right.$ per $250 \mathrm{~cm}^{3}$ sample). A further 8 dissolved oxygen and 6 DIC sample bottles were clamped to perspex bottle racks to enable a light/dark bottle incubation. Sample bottles were incubated in situ whenever possible; however, when logistics demanded, simulated in situ incubations were undertaken at $1 \mathrm{~m}$ depth alongside the wharf. Samples were fixed at the end of the $24 \mathrm{~h}$ incu- 


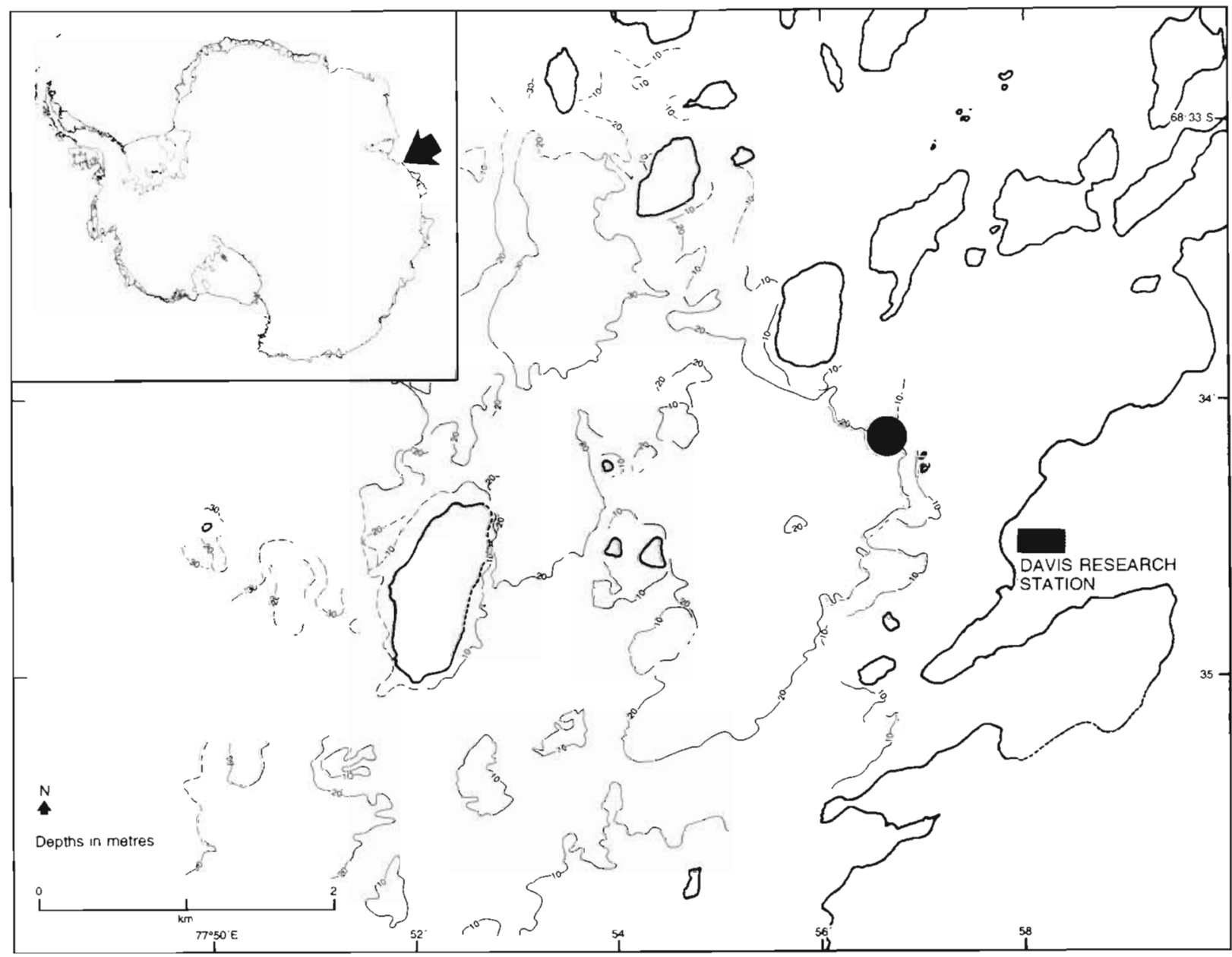

Fig. 1 Study area showing location of sampling site

at O'Gorman Rocks in the vicinity of the Australian Antarctic station of Davis

bation and stored underwater until analysis (within $24 \mathrm{~h}$ ) as described above. After analysis, DIC sample bottles were acid-washed $(10 \% \mathrm{HCl})$ in order to remove any trace of mercuric chloride which would affect any subsequent incubation.

The remainder of the collected $60 \mathrm{dm}^{3}$ water sample was used to assess the size distribution of community respiration. A reverse flow gravity fed fractionation system using $142 \mathrm{~mm}$ diameter filters of pore size 18, 2 and $0.8 \mu \mathrm{m}$ as described in Boyd et al. (1995) and Blight et al. (1995) was set up to separate the plankton population into $<18,<2$ and $<0.8 \mu \mathrm{m}$ size classes. Water samples from each of these size classes were siphoned into eight $50 \mathrm{~cm}^{3}$ borosilicate glass bottles. Four bottles were fixed immediately, and 4 were incubated in the dark for $24 \mathrm{~h}$.

On 2 occasions time series experiments were undertaken to check for linearity with time in respiration rate. Bulk water samples (either unfractionated or fractionated through a $50 \mu \mathrm{m}$ filter) were collected and distributed into 22 borosilicate glass bottles. Four samples were fixed immediately and the remainder incubated in the dark at surface water temperature. Triplicate samples were fixed after each of $2,4,6,9$, 12 and $24 \mathrm{~h}$.

NCP was calculated from the net flux of dissolved oxygen and DIC in the 'light/dark' bottles, DCR as the decrease in dissolved oxygen and increase in DIC in the 'dark' bottles, and GP as the difference in dissolved oxygen and DIC between the means of the 'light/dark' bottles and the 'dark' bottles. All rates are presented as mmol $\mathrm{m}^{-3} \mathrm{~d}^{-1}( \pm \mathrm{SE})$. Mean production rates which were numerically less than the standard error on the mean were excluded from analysis $(n=1)$. The mean of the standard errors of the NCP and DCR rate measurements derived from $\mathrm{O}_{2}$ flux $(\mathrm{n}=22)$ was $1.2 \mathrm{mmol} \mathrm{O}_{2}$ $\mathrm{m}^{-3} \mathrm{~d}^{-1}$ and that of the DIC measurements $(\mathbf{n}=19)$ was $1.5 \mathrm{mmol} \mathrm{C} \mathrm{m} \mathrm{m}^{-3} \mathrm{~d}^{-1}$. Coulometric analyses of 3 certified DIC reference materials within the time frame and chemical conditions associated with the analysis of zero/light/dark bottle samples on a single analysis day gave an estimate of short-term ( 8 to 12 h) reproducibil- 
ity $\left(\mathrm{SD}=1 \mathrm{mmol} \mathrm{C} \mathrm{m}^{-3} \mathrm{~d}^{-1}\right)$ and hence the minimum production rate discernible with the DIC analytical system during this study.

Community photosynthetic quotients and respiratory quotients were calculated as $\mathrm{GP}\left[\mathrm{O}_{2}\right] / \mathrm{GP}[\mathrm{DIC}]$ and $\mathrm{DCR}[\mathrm{DIC}] / \mathrm{DCR}\left[\mathrm{O}_{2}\right]$ respectively and the standard error of the quotients was determined from:

$$
\text { SE of } X / Y=1 / Y^{2} \sqrt{Y^{2} X^{2}+X^{2} Y^{2}}
$$

where $X$ and $Y$ are means, $X$ is the standard error of $X$ and $y$ is the standard error of $Y$.

${ }^{14} \mathrm{C}$ incorporation primary production $\left(\mathrm{PP}\left[{ }^{14} \mathrm{C}\right]\right)$. Measurement of radioactive carbon uptake was based on the technique originally described by Steeman Nielsen (1952). Five light and 2 dark $500 \mathrm{~cm}^{3}$ samples of the bulk water were incubated for $24 \mathrm{~h}$ alongside the samples used for determination of GP, NCP and DCR. Size fractionation of ${ }^{14} \mathrm{C}$ incorporation into $>18 \mu \mathrm{m}$, 18-2 $\mu \mathrm{m}$ and 2-0.2 $\mathrm{m}$ size classes was achieved by sequential filtration through 18,2 and $0.2 \mu \mathrm{m}$ pore size polycarbonate filters (Joint \& Pomroy 1983). Subsamples of the filtrate were treated as described by Li \& Goldman (1981) for the determination of photosynthetically fixed dissolved organic carbon (PDOC). The external standard, channel ratio method was used to determine the efficiency of liquid scintillation counts. Concomitant DIC measurements (see above) were used in the calculation of photosynthetic carbon fixation. The amount of total carbon fixed was calculated from the sum of the fractions and PDOC measurements after correction for dark ${ }^{14} \mathrm{C}$ incorporation and $5 \%$ isotope discrimination. The mean standard error of the photosynthetic $\mathrm{PP}\left[{ }^{14} \mathrm{C}\right]$ measurements was $0.9 \mathrm{mmol} \mathrm{C}$ $\mathrm{m}^{-3} \mathrm{~d}^{-1}(\mathrm{n}=11)$.
Chlorophyll a concentration. Triplicate $500 \mathrm{~cm}^{3}$ subsamples were filtered onto $47 \mathrm{~mm}$ diameter $\mathrm{GF} / \mathrm{F}$ filters for the determination of chlorophyll a concentration. Pigments were extracted in $90 \%$ acetone for $24 \mathrm{~h}$ in the dark and absorbance was measured with a spectrophotometer according to Strickland \& Parsons (1972).

Diel changes in dissolved oxygen and photosynthetically available radiation (PAR). An in situ autonomous productivity rig incorporating logging sensors for ambient temperature and dissolved oxygen, and PAR (QSP-200, Biospherical Instruments, Inc., San Diego, USA), temperature and dissolved oxygen within a $5 \mathrm{dm}^{3}$ perspex incubator (Langdon 1993a, Langdon et al. 1995) was deployed at a depth of $5 \mathrm{~m}$ at O'Gorman Rocks. The perspex incubator was programmed to open, flush and close once every $24 \mathrm{~h}$ to enable the measurement of diel changes in dissolved oxygen concentration. Water samples for Winkler oxygen titrations were collected at regular intervals alongside the in situ rig in order to calibrate the oxygen electrodes.

\section{RESULTS}

\section{Temporal progression}

Beneath the $2 \mathrm{~m}$ fast ice which covered the sampling site on 9 December 1993 (Day 343), the water column was completely mixed, with concentrations of dissolved oxygen and DIC of $433 \mathrm{mmol} \mathrm{O}_{2} \mathrm{~m}^{-3}$ and $2098 \mathrm{mmol} \mathrm{C} \mathrm{m}^{-3}$ respectively (Fig. 2). Six days later (Day 349), supersaturation of dissolved oxygen, a substantial decrease in DIC concentration and rates of

Table 1. Gross production (GP), net community production (NCP) and dark community respiration (DCR) $\left(\mathrm{mmol} \mathrm{O}_{2} \mathrm{~m}^{-3} \mathrm{~d}^{-1} \pm \mathrm{SE}\right)$ and (mmol C m $\mathrm{m}^{-3} \mathrm{~d}^{-1} \pm \mathrm{SE}$ ), primary production (PP) $\left({ }^{14} \mathrm{C}\right.$ incorporation) (mmol C m $\mathrm{m}^{-3} \mathrm{~d}^{-1}$ ) and chlorophyll a concentration (mg chl a m${ }^{-3}$ ) at O'Gorman Rocks from 16 December 1993 to 12 February 1994. nd = not determined

\begin{tabular}{|c|c|c|c|c|c|c|c|c|}
\hline \multirow[t]{2}{*}{ Date } & \multicolumn{3}{|c|}{$\begin{array}{l}\text { Dissolved oxygen flux } \\
\left(\mathrm{mmol} \mathrm{O}_{2} \mathrm{~m}^{-3} \mathrm{~d}^{-1} \pm \mathrm{SE}\right)\end{array}$} & \multicolumn{4}{|c|}{$\begin{array}{l}\text { Carbon flux } \\
\left(\mathrm{mmol} \mathrm{C} \mathrm{m} \mathrm{m}^{-3} \mathrm{~d}^{-1} \pm \mathrm{SE}\right)\end{array}$} & \multirow{2}{*}{ 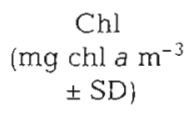 } \\
\hline & $\mathrm{GP}\left[\mathrm{O}_{2}\right\}$ & $\mathrm{NCP}\left[\mathrm{O}_{2}\right]$ & $\operatorname{DCR}\left[\mathrm{O}_{2}\right]$ & GP[DIC] & $\mathrm{NCP}[\mathrm{DIC}]$ & DCR[DIC] & $\mathrm{PP}\left[{ }^{14} \mathrm{C}\right]$ & \\
\hline 16 Dec 93 & $12.2 \pm 2.3$ & $7.4 \pm 2.3$ & $4.8 \pm 0.2$ & $7.4 \pm 0.7$ & $4.7 \pm 1.0$ & $2.7 \pm 0.9$ & $3.0 \pm 0.3$ & $5.6 \pm 0.1$ \\
\hline $29 \operatorname{Dec} 93$ & $32.0 \pm 0.4$ & $28.6 \pm 0.4$ & $3.4 \pm 0.2$ & $27.6 \pm 0.8$ & $23.4 \pm 0.8$ & $4.2 \pm 0.7$ & $19.9 \pm 1.4$ & $5.4 \pm 0.9$ \\
\hline $10 \mathrm{Jan} 94$ & $21.2 \pm 0.4$ & $18.3 \pm 0.2$ & $2.9 \pm 0.4$ & nd & nd & nd & $1.1 .1 \pm 0.4$ & $6.8 \pm 0.6$ \\
\hline 17 Jan 94 & $45.0 \pm 0.3$ & $38.1 \pm 0.3$ & $6.9 \pm 0.2$ & $25.1 \pm 3.2$ & $18.9 \pm 3.6$ & $6.2 \pm 3.1$ & $20.9 \pm 0.9$ & $13.1 \pm 0.2$ \\
\hline 19 Jan 94 & $30.8 \pm 3.5$ & $25.8 \pm 3.5$ & $5.0 \pm 0.8$ & $22.9 \pm 2.1$ & $19.6 \pm 1.7$ & $3.3 \pm 2.1$ & $15.5 \pm 1.6$ & $15.0 \pm 0.7$ \\
\hline $23 \operatorname{Jan} 94$ & $38.6 \pm 3.4$ & $30.2 \pm 3.7$ & $8.4 \pm 3.2$ & $33.5 \pm 1.8$ & $27.5 \pm 1.9$ & $6.0 \pm 0.9$ & $23.7 \pm 2.9$ & $22.2 \pm 1.3$ \\
\hline $27 \operatorname{Jan} 94$ & $35.4 \pm 2.5$ & $21.4 \pm 2.8$ & $14.0 \pm 2.5$ & $24.1 \pm 1.6$ & $11.4 \pm 2.0$ & $12.7 \pm 1.6$ & $13.9 \pm 0.9$ & $19.5 \pm 1.0$ \\
\hline 30 Jan 94 & $17.6 \pm 2.3$ & $14.7 \pm 1.4$ & $2.9 \pm 1.8$ & $16.0 \pm 1.3$ & $10.5 \pm 0.9$ & $5.5 \pm 1.2$ & $10.8 \pm 0.4$ & $13.0 \pm 0.5$ \\
\hline 02 Feb 94 & $24.6 \pm 1.3$ & $19.5 \pm 1.3$ & $5.1 \pm 0.2$ & $16.1 \pm 1.6$ & $10.8 \pm 1.5$ & $5.3 \pm 1.4$ & $12.2 \pm 0.4$ & $17.2 \pm 0.4$ \\
\hline 07 Feb 94 & $30.1 \pm 0.4$ & $25.2 \pm 0.4$ & $4.9 \pm 0.3$ & $19.9 \pm 1.3$ & $16.6 \pm 1.4$ & $3.3 \pm 1.2$ & $9.8 \pm 0.3$ & $10.4 \pm 0.4$ \\
\hline 12 Feb 94 & $3.2 \pm 0.4$ & $0.9 \pm 0.3$ & $2.3 \pm 0.3$ & & $3.7 \pm 1.3$ & $1.0 \pm 1.2^{a}$ & $2.1 \pm 0.2$ & $1.9 \pm 0.1$ \\
\hline
\end{tabular}




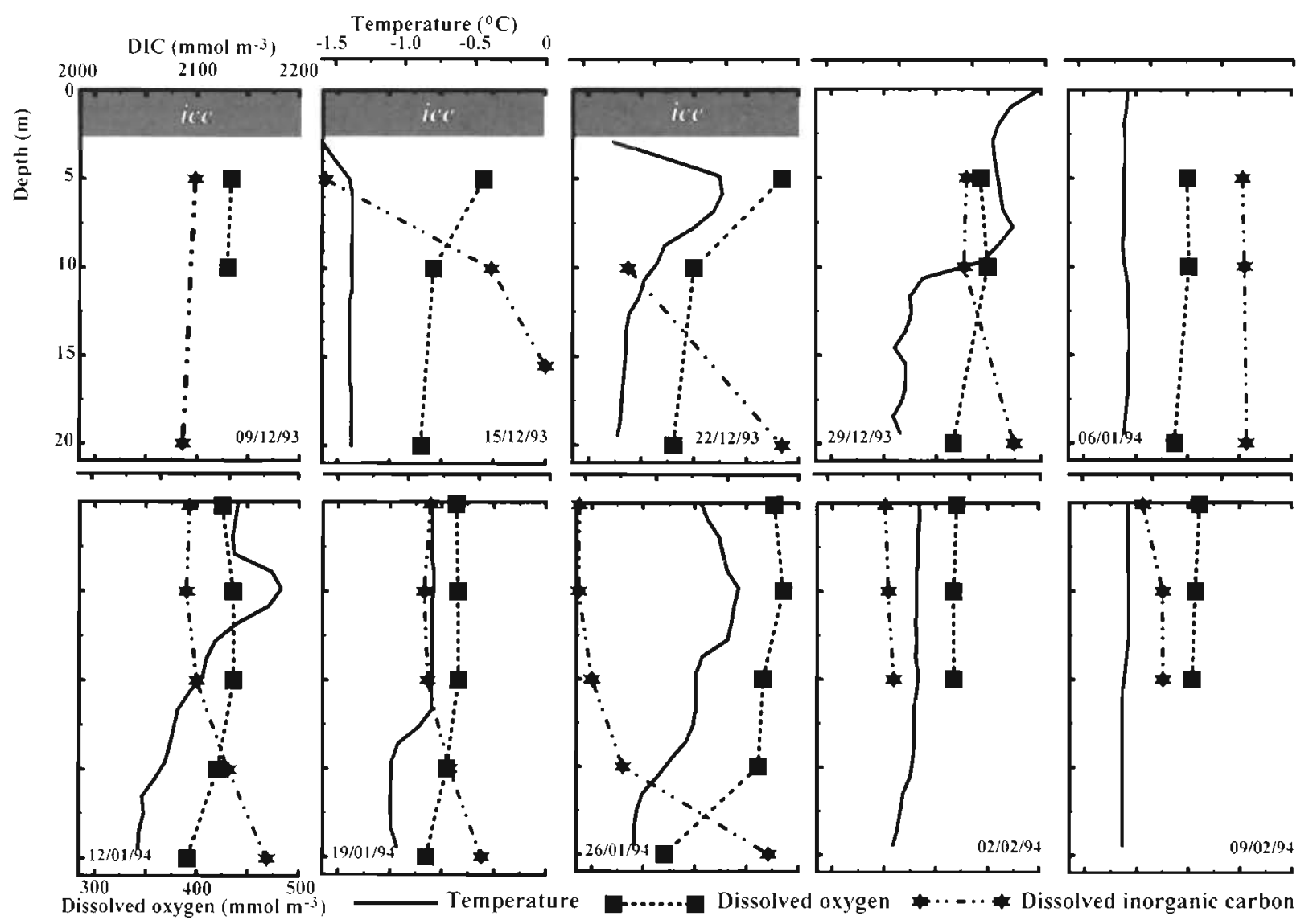

Fig. 2. Depth profiles of temperature $\left({ }^{\circ} \mathrm{C}\right)$, dissolved inorganic carbon (DIC) $\left(\mathrm{mmol} \mathrm{C} \mathrm{m}{ }^{-3}\right)$ and dissolved oxygen $\left(\mathrm{mmol} \mathrm{O}_{2} \mathrm{~m}^{-3}\right)$ at O'Gorman Rocks. In situ temperature was not measured on 9 December 1993. Sample dates given as d/mo/yr

gross production of $7 \mathrm{mmol} \mathrm{C} \mathrm{m}^{-3} \mathrm{~d}^{-1}$ indicated active autotrophic growth (Fig. 3, Table 1) despite the low irradiance levels beneath the ice (e.g. Fig. 4a; Days 350 to 352). Cryptomonas sp. was the dominant autotroph

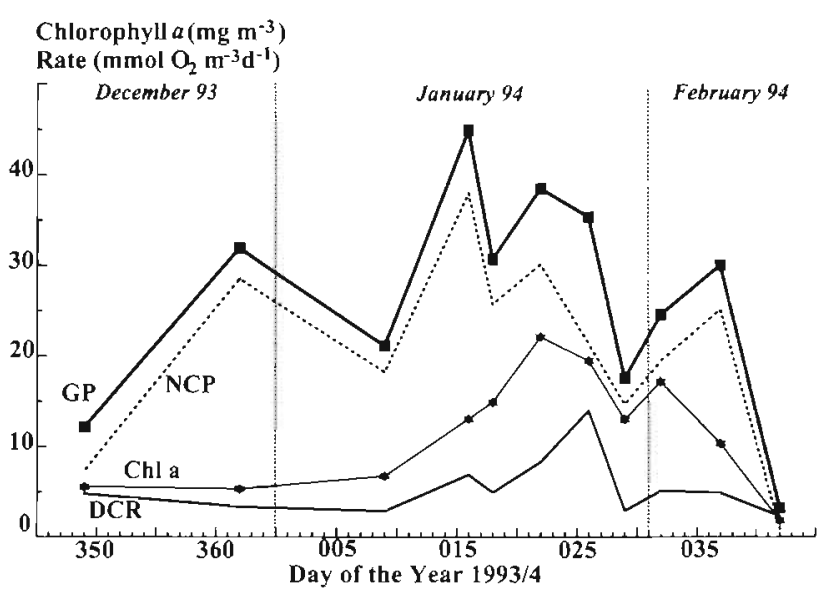

Fig. 3. Gross production $\left(\mathrm{GP}\left[\mathrm{O}_{2}\right]\right)$, net community production $\left(\mathrm{NCP}\left[\mathrm{O}_{2}\right]\right)$ and dark community respiration $\left(\mathrm{DCR}\left[\mathrm{O}_{2}\right]\right)(\mathrm{mmol}$ $\mathrm{O}_{2} \mathrm{~m}^{-3} \mathrm{~d}^{-1}$ ) and chlorophyll a ( $\mathrm{mg} \mathrm{chl} a \mathrm{~m}^{-3}$ ) measured at 3 to $4 \mathrm{~d}$ intervals at O'Gorman Rocks between December 1993 and February 1994 under the ice, with cell counts of $2-3 \times 10^{6} \mathrm{dm}^{-3}$ (Gibson et al. 1997).

When the ice broke up and moved away (23 December 1993, Day 357), the resultant rise in light availability (e.g. Fig. 4b; Day 364) was associated with a 4 -fold increase in GP[DIC] (Fig. 3; between 16 December

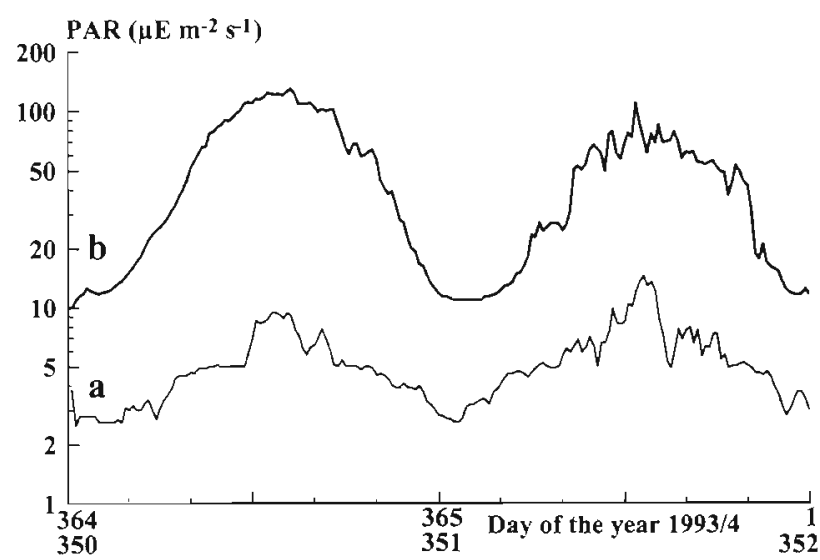

Fig. 4. Diel change in photosynthetically available radiation (PAR) $\left(\mu \mathrm{E} \mathrm{m}^{-2} \mathrm{~s}^{-1}\right)$ (a) beneath $2 \mathrm{~m}$ fast ice between Days 350 and 352 of 1993 and (b) in open water between Day 364 of 1993 and Day 1 of 1994 


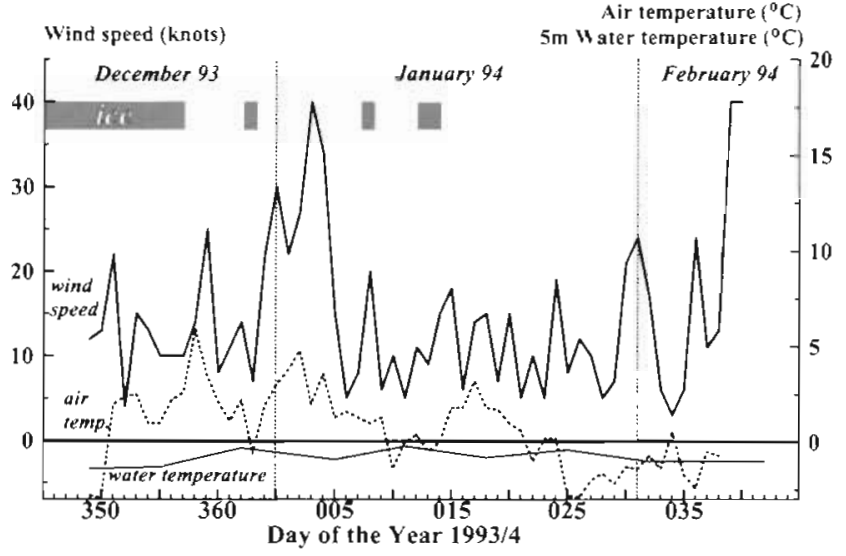

Fig. 5. Variability of air and water ( $5 \mathrm{~m}$ depth) temperature $\left({ }^{\circ} \mathrm{C}\right)$ and wind speed (knots) during the sample period. The presence and breakout of fast ice, pack ice and ice floes is also indicated

1993, Day 349, and 29 December 1993, Day 362), a 6 fold increase in ${ }^{14} \mathrm{C}$ incorporation (Table 1), and Phaeocystis $\mathrm{sp}$. became the dominant autotroph $\left(4 \times 10^{6}\right.$ cells $\mathrm{dm}^{-3}$, Gibson et al. 1997). Strong winds on 2 to 5 January 1994 (30 to 40 knots; Fig. 5) were associated with a cooler, well-mixed water column and a reduction in gross $\left[\mathrm{O}_{2}\right]$ and primary $\left[{ }^{14} \mathrm{C}\right]$ production (Figs. $2 \& 3$, Table 1). For a further $5 \mathrm{~d}$, icebergs and floes originating from further east along the coast moved across the sampling site. With a reduction in wind strength, and an increase in surface water temperature, gross production $\left(\mathrm{GP}\left[\mathrm{O}_{2}\right]\right.$ ) increased to $45 \mathrm{mmol} \mathrm{O} \mathrm{m}^{-3} \mathrm{~d}^{-1}$ on 17 January 1994. Autotrophic biomass peaked at $22 \mathrm{mg}$ chl $a \mathrm{~m}^{-3}$ and GP[DIC] and PP $\left.\mid{ }^{14} \mathrm{C}\right]$ reached maxima of 33 and $24 \mathrm{mmol} \mathrm{C} \mathrm{m}{ }^{-3} \mathrm{~d}^{-1}$ on 23 January 1994 (Table 1). The algal community was now dominated by the diatoms Actinocyclus sp., Asteromphalus sp., Chaetoceros spp., Coscinodiscus spp. and Thalassiosira spp. (Archer et al. 1996a). Post incubation size fractionation of the $\mathrm{NaH}^{14} \mathrm{CO}_{2}$ incorporation samples suggested the $>18 \mu \mathrm{m}$ fraction accounted for more than $60 \%$ of the ${ }^{14} \mathrm{C}$ assimilation (Table 2). Plankton community dark respiration peaked 4 d later $\left(13 \mathrm{mmol} \mathrm{C} \mathrm{m}^{-3} \mathrm{~d}^{-1}\right)$. As wind speeds increased in early February, the water column returned to a cooler, well-mixed situation (Fig. 2; 2 February 1994). After 7 February 1994 (Day 38), GP, NCP, DCR and chlorophyll a concentration all decreased abruptly (Fig. 3 , Table 1) to $3 \mathrm{mmol} \mathrm{O}_{2} \mathrm{~m}^{-3}$ $\mathrm{d}^{-1}, 0.9 \mathrm{mmol} \mathrm{O} \mathrm{m}^{-3} \mathrm{~d}^{-1}, 2.3 \mathrm{mmol} \mathrm{O}_{2} \mathrm{~m}^{-3} \mathrm{~d}^{-1}$ and

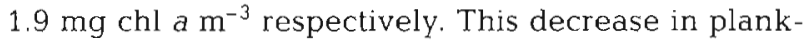
ton activity and biomass was again associated with a substantial increase in wind speed (Fig. 5).

\section{Comparison of measurements}

The concomitant measurement of photosynthesis by 4 methods (oxygen electrodes, flux of dissolved oxygen, flux of DIC and assimilation of ${ }^{14} \mathrm{C}$ ) and community respiration by 2 methods (flux of dissolved oxygen and flux of DIC) enabled field comparisons of rates to be made along with the derivation of photosynthetic and respiratory quotients.

Intermittent ice floes and bergs restricted the safe deployment of the autonomous oxygen electrode rig. On the single occasion (30 December 1993, Day 365) when NCP could be derived from the net change in oxygen concentration over a $24 \mathrm{~h}$ deployment, NCP was calculated to be $19 \mathrm{mmol} \mathrm{O}_{2} \mathrm{~m}^{-3} \mathrm{~d}^{-1}$ (Fig. 6). NCP estimated from the change in dissolved oxygen in $150 \mathrm{~cm}^{3}$ glass bottles was $29 \mathrm{mmol} \mathrm{O}_{2} \mathrm{~m}^{-3} \mathrm{~d}^{-1}$ on the previous day (29 December 1993, Day 364) (Table 1). This daily variability in NCP is not inconsistent with the variability in integrated irradiance levels between the two days (Day $364=1398 \mu \mathrm{E} \mathrm{m}^{-2}$; Day $365=913 \mu \mathrm{E}$ $\mathrm{m}^{-2}$ ) (Fig. 4). Concomitant production rates derived from a $5 \mathrm{dm}^{3}$ autonomous oxygen electrode rig and

Table 2. Total (mmol $\mathrm{C} \mathrm{m}^{-3} \mathrm{~d}^{-1}$ ) and size-fractionated primary production (PP ${ }^{14} \mathrm{Cl}$ ), and photosynthetically fixed dissolved organic carbon (PDOC) (as percentage of total)

\begin{tabular}{|c|c|c|c|c|c|}
\hline Date & $\begin{array}{c}\text { Total PP }\left[{ }^{14} \mathrm{C}\right] \\
\left(\text { mmol } \mathrm{Cm}^{-3} \mathrm{~d}^{-1} \pm \mathrm{SE}\right)\end{array}$ & $\begin{array}{c}>18 \mu \mathrm{m} \\
(\text { as } \% \text { of total })\end{array}$ & $\begin{array}{c}<18>2 \mu \mathrm{m} \\
(\text { as } \% \text { of total) }\end{array}$ & $\begin{array}{l}<2>0.2 \mu \mathrm{m} \\
\text { (as } \% \text { of total) }\end{array}$ & $\begin{array}{c}\text { PDOC } \\
\text { (as } \% \text { of total) }\end{array}$ \\
\hline 16 Dec 93 & $3.0 \pm 0.3$ & 3 & 52 & 20 & 25 \\
\hline 29 Dec 93 & $19.8 \pm 1.4$ & 72 & 9 & 2 & 17 \\
\hline $10 \operatorname{Jan} 94$ & $11.1 \pm 0.4$ & 72 & 13 & 3 & 12 \\
\hline $17 \operatorname{San} 94$ & $21.0 \pm 0.9$ & 75 & 11 & 3 & 11 \\
\hline $19 \operatorname{Jan} 94$ & $15.5 \pm 1.6$ & 66 & 16 & 3 & 15 \\
\hline $23 \operatorname{Jan} 94$ & $23.7 \pm 2.9$ & 71 & 10 & 6 & 13 \\
\hline $27 \operatorname{Jan} 94$ & $13.9 \pm 0.9$ & 69 & 10 & 4 & 17 \\
\hline $30 \mathrm{Jan} 94$ & $10.8 \pm 0.4$ & 72 & 13 & 5 & 10 \\
\hline 02 Feb 94 & $12.2 \pm 0.4$ & 65 & 17 & 5 & 13 \\
\hline 07 Feb 94 & $9.8 \pm 0.3$ & 75 & 16 & 3 & 6 \\
\hline 12 Feb 94 & $2.1 \pm 0.2$ & 64 & 17 & 5 & 14 \\
\hline
\end{tabular}




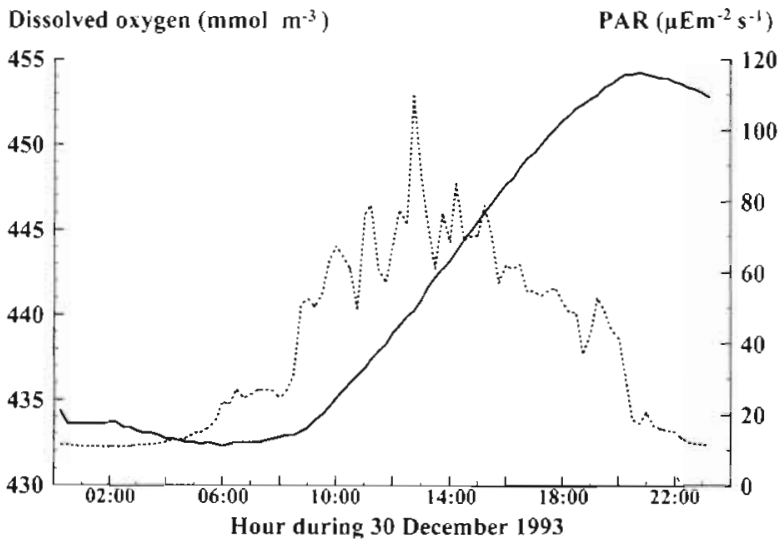

Fig. 6. Diel change in dissolved oxygen $\left(\mathrm{mmol} \mathrm{m}^{-3}\right)$ and PAR $\left(\mu \mathrm{E} \mathrm{m}^{-2} \mathrm{~s}^{-1}\right)$ measured with an in situ autonomous rig

from Winkler titration of incubated seawater samples have previously been in excellent agreement (Langdon 1992).

The concomitant determination of photosynthesis from changes in DIC and from ${ }^{14} \mathrm{C}$ uptake enabled an estimate of the extent to which the ${ }^{14} \mathrm{C}$ uptake method measured gross or net production in this instance. Fig. 7 presents the 2 measurements of carbon flux and shows that the ${ }^{14} \mathrm{C}$ fixation data was consistently lower than the GP[DIC] measurements, and in $56 \%$ of cases, was also lower than the NCP[DIC] determinations (data lies above the 1:1 line). A Student's t-test suggests that ${ }^{14} \mathrm{C}$ accumulation was significantly different from NCP[DIC] and GP[DIC]. If GP[DIC] is assumed to be the definitive measure of photosynthesis (for which one must assume that light and dark respiration are equal), then $P P\left({ }^{14} \mathrm{C}\right.$ ) underestimated photosynthesis by an average of $35 \%$ (range $=17$ to $59 \%, \mathrm{n}=9$ ).

Assimilation numbers for $\mathrm{PP}\left[{ }^{14} \mathrm{C}\right] / \mathrm{chl}$ ( $\mathrm{mg} \mathrm{C}$ [mg chl $\left.a)^{-1} \mathrm{~d}^{-1}\right)$ lay in the range 6 to $44(\mathrm{n}=11$; mean $=15)$ and

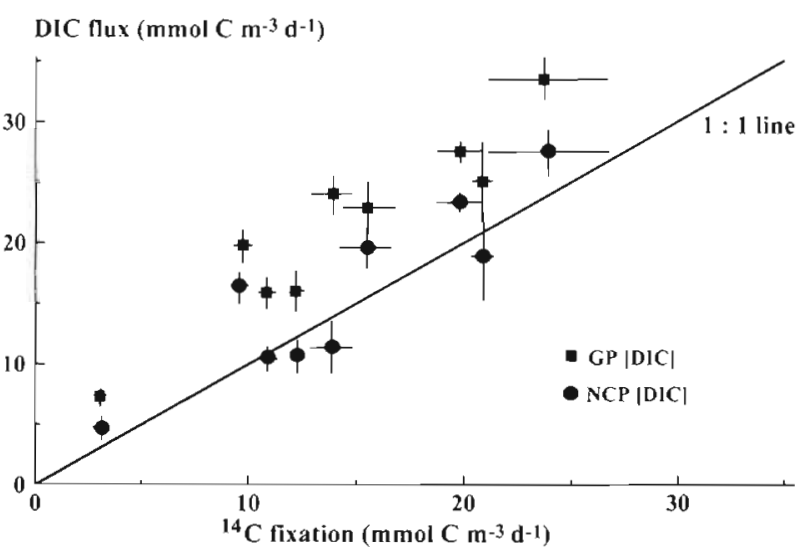

Fig. 7. DIC flux (mmol $\mathrm{C} \mathrm{m}^{-3} \mathrm{~d}^{-1} \pm \mathrm{SE}$ ) plotted against ${ }^{14} \mathrm{C}$ fixation (mmol $\mathrm{C} \mathrm{m}^{-3} \mathrm{~d}^{-1} \pm \mathrm{SE}$ ). $\mathbf{G P}[\mathrm{DIC}]_{i} \bullet \mathrm{NCP}[\mathrm{DIC}]$

for GP[DIC]/chl (mg C [mg chl a $]^{-1} \mathrm{~d}^{-1}$ ) lay between 6 and $62(\mathrm{n}=9$; mean $=21)$ (Table 3$)$. The highest values in each case (44 and 62) occurred on 29 December 1993, when Phaeocystis was dominant. When these are removed from the calculations, the seasonal means fall to 12 and 16 respectively $\left(0.7\right.$ and $0.9 \mathrm{mg} \mathrm{C}\left[\mathrm{mg} \mathrm{chl} \mathrm{a}^{-1}\right.$ $\mathrm{h}^{-1}$ based on an $18 \mathrm{~h}$ photoperiod). These lie within the range ( 0.5 to $28 \mathrm{mg} \mathrm{C}[\mathrm{mg} \mathrm{chl} \mathrm{a}]^{-1} \mathrm{~d}^{-1}$ ) calculated by Whitaker (1982) from depth integrated measurements of $\mathrm{PP}\left[{ }^{14} \mathrm{C}\right]$ made at Signy Island, Antarctic, and are comparable to maximum assimilation numbers derived from $\mathrm{PP}\left[{ }^{14} \mathrm{C}\right]$ versus irradiance curves of Antarctic phytoplankton $\left(0.7\right.$ to $4 \mu \mathrm{g} \mathrm{C}[\mu \mathrm{g} \mathrm{chl} \mathrm{a}]^{-1} \mathrm{~h}^{-1}$; Sakshaug \& Holm-Hansen $1986,0.5$ to $1.0 \mathrm{mg} \mathrm{C}[\mathrm{mg} \mathrm{chl} \mathrm{a}]^{-1} \mathrm{~h}^{-1}$; Boyd et al. 1995, 0.2 to $3 \mu \mathrm{g} \mathrm{C}[\mu \mathrm{g} \text { chl a }]^{-1} \mathrm{~h}^{-1}$; Savidge et al. 1995).

Photosynthetic and respiratory quotients $(\mathrm{PQ}$ and $R Q)$ were determined from model II major reduced axis linear regressions of GP[DIC] against $\mathrm{GP}\left[\mathrm{O}_{2}\right](\mathrm{PQ}$ $\left.=1.33 \pm 0.23 ; n=9 ; r^{2}=0.86\right)$ and of DCR[DIC] against

Table 3. Photosynthetic and respiratory quotients $\left(P Q=\Delta \mathrm{O}_{2} / \Delta \mathrm{DIC} ; \mathrm{RQ}=\Delta \mathrm{DIC} / \Delta \mathrm{O}_{2}\right), \mathrm{P}: \mathrm{R}$ ratios and assimilation numbers (mg $\mathrm{C}$

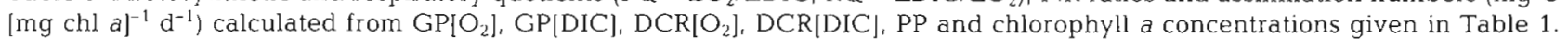
nd $=$ not determined

\begin{tabular}{|c|c|c|c|c|c|c|}
\hline Date & $\mathrm{PQ} \pm \mathrm{SE}$ & $\mathrm{RQ} \pm \mathrm{SE}$ & $\mathrm{P}: \mathrm{R}\left[\mathrm{O}_{2}\right]$ & $P: R|D I C|$ & $\begin{array}{c}\mathrm{PP}\left[{ }^{14} \mathrm{C}\right] / \mathrm{chl} a \\
\left(\mathrm{mg} \mathrm{C}[\mathrm{mg} \mathrm{chl} \mathrm{a}]^{-1} \mathrm{~d}^{-1}\right)\end{array}$ & $\begin{array}{c}\mathrm{GP}[\mathrm{DIC}] / \mathrm{chl} a \\
\left(\mathrm{mg} \mathrm{C}[\mathrm{mg} \mathrm{chl} \mathrm{a}]^{-1} \mathrm{~d}^{-1}\right)\end{array}$ \\
\hline $16 \operatorname{Dec} 93$ & $1.7 \pm 0.4$ & $0.6 \pm 0.2$ & 2.5 & 2.7 & 7 & 6 \\
\hline $29 \mathrm{Dec} 93$ & $1.2 \pm 0.1$ & $1.2 \pm 0.2$ & 9.4 & 6.6 & 44 & 62 \\
\hline $10 \operatorname{Jan} 94$ & nd & nd & 7.3 & nd & 20 & nd \\
\hline $17 \operatorname{Jan} 94$ & $1.8 \pm 0.2$ & $0.9 \pm 0.5$ & 6.5 & 4.1 & 19 & 23 \\
\hline $19 \operatorname{Jan} 94$ & $1.3 \pm 0.2$ & $0.7 \pm 0.4$ & 6.2 & 6.9 & 12 & 18 \\
\hline $23 \operatorname{Jan} 94$ & $1.2 \pm 0.1$ & $0.7 \pm 0.3$ & 4.6 & 5.6 & 13 & 18 \\
\hline $27 \operatorname{Jan} 94$ & $1.5 \pm 0.1$ & $0.9 \pm 0.2$ & 2.5 & 1.9 & 9 & 15 \\
\hline $30 \mathrm{Jan} 94$ & $1.1 \pm 0.2$ & $1.9 \pm 1.3$ & 6.0 & 29 & 10 & 15 \\
\hline 02 Feb 94 & $1.5 \pm 0.2$ & $1.0 \pm 0.3$ & 4.8 & 3.1 & 8 & 11 \\
\hline 07 Feb 94 & $1.5 \pm 0.1$ & $0.7 \pm 0.3$ & 6.1 & 6.0 & 11 & 23 \\
\hline 12 Feb 94 & nd & nd & 1.4 & nd & 13 & nd \\
\hline
\end{tabular}




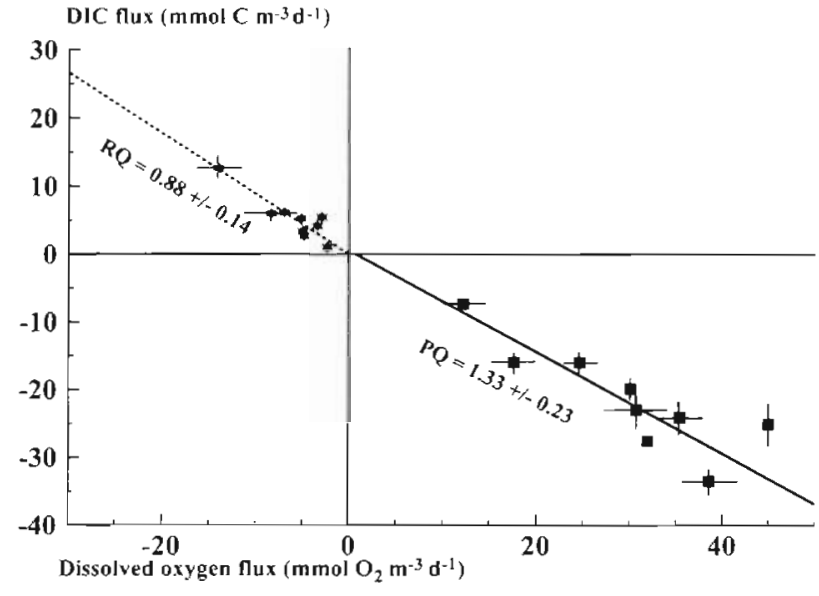

Fig. 8. DIC flux (ロ: GP; $*$ DCR) (mmol C m $\mathrm{m}^{-3} \mathrm{~d}^{-1} \pm \mathrm{SE}$ ) plotted against dissolved oxygen flux (mmol $\mathrm{O}_{2} \mathrm{~m}^{-3} \mathrm{~d}^{-1} \pm \mathrm{SE}$ ) The solid and dotted lines are major reduced axes linear regres. sion fits to the GP and DCR data respectively (not forced through zero) providing estimates of the photosynthetic (1.33 $\pm 0.23)$ and respiratory quotients $(0.88 \pm 0.14)$

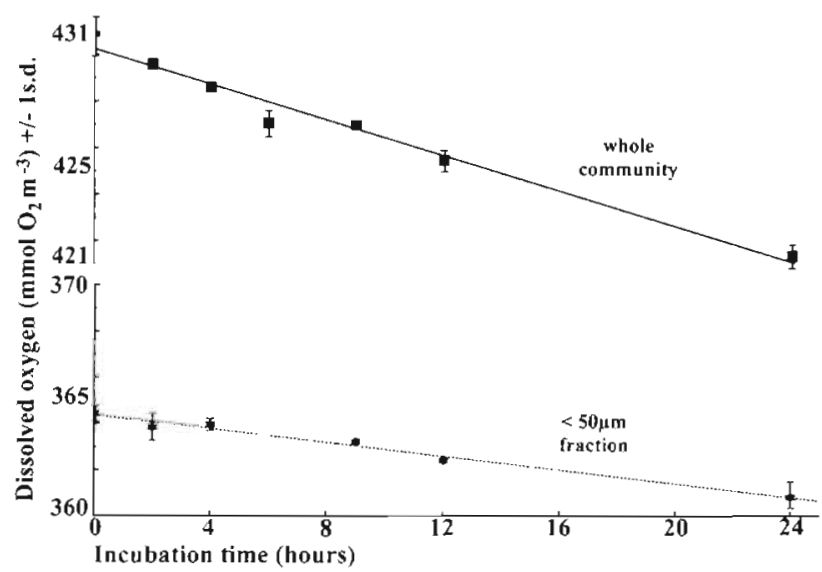

Fig. 9. Decrease in oxygen concentration $\left(\mathrm{mmol} \mathrm{O} \mathrm{O}_{2} \mathrm{~m}^{-3} \pm 1\right.$ $\mathrm{SD}$ ) of a whole community sample and a $<50 \mu \mathrm{m}$ fractionated sample during the incubation period. Least squares regression lines are shown

$\mathrm{DCR}\left[\mathrm{O}_{2}\right]\left(\mathrm{RQ}=0.88 \pm 0.14 ; \mathrm{n}=9 ; \mathrm{r}^{2}=0.88\right)($ Fig. 8 , Table 3)

Calculated ratios of photosynthesis to respiration (P:R) lay between 2 and 9 (Table 3). Arístegui et al. (1996) measured P:R ratios in the range 2 to 8 at 4 stations near the Antarctic Peninsula during spring/summer 1993.

Dark community respiration was linear over $24 \mathrm{~h}$ (Fig. 9), indicating that artifacts due to constraining the microbial population in a small glass bottle over these time scales seen by other workers (Pomeroy et al. 1994 and references therein) were not apparent in the respiration data during the present study. Regression coefficients were 0.97 and 0.98 respectively for an unfrac- tionated sample incubated on 19 January 1994 and a $<50 \mu \mathrm{m}$ sample incubated on 3 February 1994. Linearity of DCR over $24 \mathrm{~h}$ was also found by Williams (1981), Blight et al. (1995) and Arístegui et al. (1996).

\section{DISCUSSION}

\section{Temporal progression}

A marked temporal change in plankton biomass and activity occurred at $\mathrm{O}^{\prime}$ Gorman Rocks, strongly associated with the physical environment of sea ice melt and wind mixing. Until 23 December, the site was covered in $2 \mathrm{~m}$ fast ice. Chlorophyll a concentrations were approximately $5 \mathrm{mg}$ chl a $\mathrm{m}^{-3}$. High oxygen supersaturation $(115 \%)$ and rates of gross production of $7 \mathrm{mmol} \mathrm{C} \mathrm{m}{ }^{-3} \mathrm{~d}^{-1}$ indicated active algal growth despite the low irradiance levels beneath the ice $\left(<10 \mu \mathrm{E} \mathrm{m}^{-2} \mathrm{~s}^{-1}\right)$ (Fig. 4 a). Similar chlorophyll a concentrations beneath sea ice near this site have been reported before. Perrin et al. (1987) measured an increase in chlorophyll a of $4 \mathrm{mg} \mathrm{m}^{-3}$ between 1 November 1982 and 9 December 1982.

Perrin et al. (1987) also highlighted the rapid succession of algal species from Amphiprora sp., Synedra sp. and Nitzschia frigida dominant on the underside of the ice, to a water column bloom of Phaeocystis pouchetti which lasted 2 wk after the ice broke out, to a bloom of Nitzschia lanceolata during January and February 1983. Davidson \& Marchant (1992) noted the high level of interannual consistency in the abundance and succession of the dominant phytoplankton at this site, when they too found high abundances $\left(6 \times 10^{7}\right.$ cells $\mathrm{dm}^{-3}$ ) of colonial $P$. pouchetii just as the ice broke out on 3 January 1989 followed by a diatom bloom 2 wk later. During the present study, a similar rapid succession in algal dominance from Cryptomonas sp. under the ice, to Phaeocystis sp. once the ice had cleared, to a diatom-dominated population during January and February 1994 occurred.

The chlorophyll a peak (22 $\mathrm{mg} \mathrm{chl}$ a $\mathrm{m}^{-3}$ ) and primary production maximum (34 mmol $\mathrm{C} \mathrm{m}^{-3} \mathrm{~d}^{-1}$ ) measured in this study are not dissimilar to coastal bloom maxima previously reported. Whitaker (1982), during a 25 mo study at a $16.5 \mathrm{~m}$ site offshore from Signy Island $\left(60^{\circ} 42^{\prime} \mathrm{S}, 45^{\circ} 36^{\prime} \mathrm{W}\right)$, recorded maxima of $14 \mathrm{mg} \mathrm{chl} \mathrm{a}$

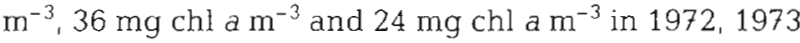
and 1974 respectively, with total ${ }^{14} \mathrm{C}$ fixation rates peaking at $29 \mathrm{mmol} \mathrm{C} \mathrm{m}{ }^{-3} \mathrm{~d}^{-1}$. Arrigo \& McClain (1994) reported Coastal Zone Colour Scanner (CZCS). derived chlorophyll concentration to peak at $22 \mathrm{mg} \mathrm{m}^{-3}$ in December 1978 in a polynya in the western Ross Sea. During the multidisciplinary RACER programme, Holm-Hansen \& Mitchell (1991) report a maximum chlorophyll a concentration of $25 \mathrm{mg}$ chl a $\mathrm{m}^{-3}$ in Janu- 
ary 1987 in the Gerlache Strait. Moline \& Prézelin (1997) measured peaks of chlorophyll a concentration and ${ }^{14} \mathrm{C}$ fixation of $29 \mathrm{mg} \mathrm{chl} \mathrm{a} \mathrm{m} \mathrm{m}^{-3}$ and $62 \mathrm{mmol} \mathrm{C} \mathrm{m}{ }^{-3}$ $\mathrm{d}^{-1}$ respectively during the austral spring/summer of 1991/1992 at a Palmer Long-Term Ecological Research (LTER) coastal site on the Antarctic Peninsula, and Arístegui et al. (1996) measured maxima of $\mathrm{GP}\left[\mathrm{O}_{2}\right.$ ] and $\mathrm{PP}\left[{ }^{14} \mathrm{C}\right]$ of $37 \mathrm{mmol} \mathrm{O} \mathrm{m}^{-3} \mathrm{~d}^{-1}$ and $17 \mathrm{mmol} \mathrm{C} \mathrm{m}{ }^{-3} \mathrm{~d}^{-1}$ in coastal waters of the Antarctic Peninsula during February 1993.

The range of community respiration $(2.3$ to $14 \mathrm{mmol}$ $\mathrm{O}_{2} \mathrm{~m}^{-3} \mathrm{~d}^{-1}$ and 2.7 to $13 \mathrm{mmol} \mathrm{C} \mathrm{m}^{-3} \mathrm{~d}^{-1}$ ) measured during the present study is higher than the range of community respiration measured for other coastal Antarctic regions. Robinson \& Williams (1993) reported a range of 0.5 to $4 \mathrm{mmol} \mathrm{O}_{2} \mathrm{~m}^{-3} \mathrm{~d}^{-1}$ near South Georgia in January 1991; Blight (1996) measured a range of 1.7 to $6 \mathrm{mmol} \mathrm{O}_{2} \mathrm{~m}^{-3} \mathrm{~d}^{-1}$ also in the vicinity of South Georgia in January 1994; Arístegui \& Montero (1995) reported a range of 0.2 to $4 \mathrm{mmol} \mathrm{O}_{2} \mathrm{~m}^{-3} \mathrm{~d}^{-1}$ in the Bransfield Strait during December 1991; Aristegui et al. (1996) reported a range of 0.2 to $5.6 \mathrm{mmol} \mathrm{O}_{2} \mathrm{~m}^{-3} \mathrm{~d}^{-1}$ in coastal waters of the Antarctic Peninsula in February 1993, and a range of 0.3 to $1.5 \mathrm{mmol} \mathrm{O}_{2} \mathrm{~m}^{-3} \mathrm{~d}^{-1}$ was measured near South Georgia during October/November 1997 (C.Robinson unpubl data). As far as we are aware, there are no previous time series community respiration measurements made in shallow Antarctic coastal waters. Previous measurements derived from a single depth profile at a specific site may have missed the time of maximum community respiration rate.

Although the frequency of sampling undertaken here was constrained by logistics, the concurrent measurements of photosynthesis and community respiration suggest temporal lags between the peak of autotrophic processes and the maximum of heterotrophic processes (Table 1). This phasing can be emphasized graphically by plotting GP against DCR (Blight et al. 1995). Fig. 10 shows the cyclicity of the peaks in autotrophy due to the Phaeocystis- and then diatomdominated blooms, in each case followed by an increase in the proportion of heterotrophy. However, in contrast to the annual time series measurements of Blight et al. (1995), the temporal measurements of the present study did not include a period of net heterotrophy (negative NCP).

A time lag between photosynthesis and community respiration has been reported before in temperate coastal waters (Blight et al. 1995). The more usual practice of determining phytoplankton and bacterioplankton abundance or activity has revealed a delay between the phytoplankton and bacterioplankton peaks in the North Sea (Billen \& Fontigny 1987), off Newfoundland (Pomeroy \& Deibel 1986), and at Davis (Davidson \& Marchant 1992). Billen \& Becquevort

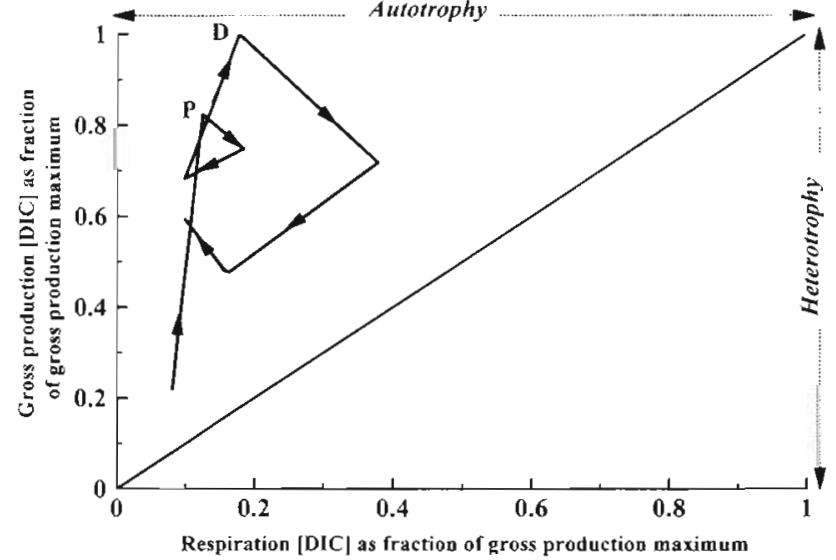

Fig. 10. Phase plot of gross production versus respiration. Arrows indicate the temporal sequence; D: diatom maximum; P: Phaeocystis maximum

(1991) hypothesised that a lag in the growth of bacterioplankton following the spring phytoplankton bloom measured in Prydz Bay in 1987 caused the lack of positive correlation between their measurements of phytoplankton and bacterioplankton biomass. As discussed by Karl (1993) and Blight et al. (1995), a time lag between autotrophic and heterotrophic growth may be due to one of a number of hypotheses, for example: (1) High molecular weight (HMW) dissolved organic matter (DOM) is produced which must be hydrolysed by ectoenzymes before it can be utilised by the bacterioplankton. (2) The production of extracellular carbon by phytoplankton is delayed. (3) The growth of bacteria and/or microzooplankton is delayed relative to the initiation of the spring bloom.

Billen \& Fontigny (1987) and Blight et al. (1995) advocated the production of HMW DOM to be the bacterial rate limiting step during temperate Phaeocystis blooms. Unfortunately DOM was not characterised during the present study; however, the rate of production of photosynthetically labelled DOC did peak at the time of the Phaeocystis bloom (29 December 1993). This suggests that it is the non- or under-utilisation, rather than the production, of DOM which causes a delay in bacterial activity. Measurements of bacterial abundance and production remained low and stable during the Phaeocystis bloom, peaking on 20 January 1994 (Leakey et al. 1996), over $20 \mathrm{~d}$ after the Phaeocystis peak and $3 \mathrm{~d}$ before the diatom-dominated chlorophyll a peak. However, this lack of close coupling between Phaeocystis growth and bacterial production could be due to the release of a bacteriocide by the actively growing Phaeocystis (Davidson \& Marchant 1987) rather than/or in addition to the production of HMW DOM. Heterotrophic nanoflagellate grazing does not appear to be the dominant control on bacterial abundance and activity at this time (Leakey et al. 1996). 
The peak in community respiration (i.e. that attribut. able to bacteria, protozooplankton and algae; see below) occurs $4 \mathrm{~d}$ after the diatom-dominated chlorophyll a peak, almost a month after the Phaeocystis peak, and coincides with a peak in heterotrophic nanoflagellate bactivory $\left(4.7 \mathrm{mg} \mathrm{C} \mathrm{m}{ }^{-3} \mathrm{~d}^{-1}\right.$ on $27 \mathrm{Janu}-$ ary 1994, Leakey et al. 1996). Heterotrophic dinoflagellate abundance, biomass and herbivory peaked on 31 January 1994, i.e. $\sim 8$ d after the diatom-dominated chlorophyll a maximum (Archer et al. 1996a). This is in contrast to the study at Davis in 1988/1989 (Davidson \& Marchant 1992) in which dinoflagellate abundance peaked after the Phaeocystis bloom and before the diatom bloom.

The abrupt decrease in photosynthesis and chlorophyll a concentration (Table 1) between 7 and 12 February 1994 is presumed to be associated with the strong winds ( 40 knots) which occurred around 10 February 1994, causing resuspension of the soft sediment below the study site and a reduction in water temperature. Previous studies in Antarctic coastal regions have shown negative correlations between mean wind speed and bloom magnitude (Clarke \& Leakey 1996).

The magnitude of phytoplankton activity and biomass, the rapid succession of dominant phytoplankton associated with sea ice melt and changes in wind speed, and the time lag between the Phaeocystis bloom and maximum bacterial activity determined in this study, therefore, are similar to results previously obtained in the coastal Antarctic. By contrast, the measurements of plankton community respiration reported here are some of the first to be made over an extended time period at a shallow $(20 \mathrm{~m})$ Antarctic site; the data are higher than discrete shipboard measurements determined in deeper Antarctic waters $(50+m)$ and demonstrate a similar time lag between maxima of autotrophic and heterotrophic processes as seen in shallow temperate regions.

\section{Comparison of measurements}

The concurrent determination of photosynthesis from changes in DIC and from the incorporation of ${ }^{14} \mathrm{C}$ suggested that ${ }^{14} \mathrm{C}$ fixation was significantly different from both NCP[DIC] and GP[DIC] (Fig. 7). If GP[DIC] is assumed to be the definitive measure of photosynthesis, then PP $\left[{ }^{14} \mathrm{C}\right]$ underestimated photosynthesis by an average of $35 \%$. This underestimation of gross production by ${ }^{14} \mathrm{C}$ incorporation has been reported previously for polar waters. Li \& Harrison (1982) found that ${ }^{14} \mathrm{C}$ assimilation determined from conventional $24 \mathrm{~h}$ endpoint measurements was only $62 \%$ of gross production determined from sequential $2 \mathrm{~h}$ incubations.
Aristegui et al. (1996), in a study of ${ }^{14} \mathrm{C}$ assimilation (12 to $14 \mathrm{~h}$ daylight incubations) and dissolved oxygen changes (24 $\mathrm{h}$ incubations) in coastal waters of the Antarctic Peninsula during austral summer, derived apparent photosynthetic quotients $\left(\mathrm{GP}\left[\mathrm{O}_{2}\right] / \mathrm{PP}\left[{ }^{14} \mathrm{C}\right]\right)$ between 1.1 and 5.5 (mean 2.68; $\mathrm{n}=19$ ), indicating a substantial underestimation of gross production by the ${ }^{14} \mathrm{C}$ method (mean underestimation of $48 \%$ assuming $\mathrm{PQ}=1.4$ ). Following conventional theory of isotope flow through the algal cell, net primary production determines the lowest numerical value of $\operatorname{PP}\left[{ }^{14} \mathrm{C}\right]$ (Williams 1993). In such a scenario $P P\left[{ }^{14} \mathrm{C}\right]$ would be greater than NCP[DIC] by an amount equal to heterotrophic respiration, and so $\mathrm{PP}\left[{ }^{14} \mathrm{C}\right]$ measurements of a mixed autotrophic and heterotrophic population in theory cannot fall below NCP[DIC]. However, in this study, more than half of the measurements of ${ }^{14} \mathrm{C}$ assimilation were lower than the concomitant NCP[DIC] determinations. Similar anomalous results have been reported before (i.e. ${ }^{14} \mathrm{C} \approx 50 \%$ net production, NP; Richardson et al. 1984, ${ }^{14} \mathrm{C}<\mathrm{NCP}\left[\mathrm{O}_{2}\right] \times \mathrm{PQ}$ of 1.4; Arístegui et al. 1996). One explanation for low rates of ${ }^{14} \mathrm{C}$ assimilation compared to NCP in some studies (e.g. that of Arístegui et al. 1996) is the lack of measurement of PDOC, and so an underestimate of ${ }^{14} \mathrm{C}$ uptake by an amount equal to the rate of phytoplankton excretion. PDOC was measured in the present study; hence, our low rates of ${ }^{14} \mathrm{C}$ assimilation are particularly worrying. PDOC was a significant fraction of the ${ }^{14} \mathrm{C}$ uptake rates (6 to $25 \%$; mean $14 \%$; Table 2) measured in this study, and agreed well with PDOC rates measured in a seasonal study of Bedford Basin ( 2 to $19 \%$ of $\mathrm{PP}\left[{ }^{14} \mathrm{C}\right.$ ); $\mathrm{n}=31$; mean $=7.5 \%$ ) (Irwin 1991).

The underestimation of photosynthesis by the ${ }^{14} \mathrm{C}$ technique seen here, and the fact that similar underestimations have been reported before, reiterate the need to routinely measure plankton production by more than 1 method in order to constrain the errors associated with the ${ }^{14} \mathrm{C}$ technique (Langdon et al. 1995) or until we can interpret ${ }^{14} \mathrm{C}$ assimilation in terms of algorithms related to plankton community and physiological state (Williams 1993).

Since most ecological models use a 'currency' of carbon units and most respiration measurements and some photosynthetic measurements are made in oxygen units, a conversion must be made in the model via the $\mathrm{PQ}$ or $\mathrm{RQ}$ (molar ratios of the fluxes of carbon and oxygen during photosynthesis and respiration respectively). While the magnitude and variability of the photosynthetic quotient are relatively well described (Laws 1991, Williams \& Robertson 1991), very few direct measurements of the respiratory flux of carbon and oxygen are available in the literature

The concurrent determination of photosynthesis and respiration from in vitro changes in both dissolved oxy- 
gen and DIC in the present study allowed the calculation of a $P Q$ and $R Q$ for the plankton population present. A linear regression of GP[DIC] against $G P\left[O_{2}\right]$ gives a $P Q$ of $1.33 \pm 0.23$ (Fig. 8). PQs calculated from discrete pairs of measurements ranged from 1.1 to 1.8 (mean 1.4) (Table 3). This mean value corresponds with stoichiometric expectations for phytoplankton utilising nitrate $\left(\mathrm{PQ}\left[\mathrm{NO}_{3}\right]\right.$ between 1.34 and 1.4) rather than ammonia ( $\mathrm{PQ}\left[\mathrm{NH}_{3}\right.$ ] between 1.03 and 1.1) (Laws 1991, Williams \& Robertson 1991). A linear regression of DCR[DIC] against DCR $\left[\mathrm{O}_{2}\right]$ gives a respiratory quotient of $0.88 \pm 0.14$ (Fig. 8, Table 1). RQs calculated from discrete pairs of measurements ranged from 0.6 to 1.9 (mean 0.95) (Table 2). The 1 standard error range of $89 \%$ of these measured RQs overlaps the boundaries set by conventional stoichiometry of heterotrophic respiration $0.97<\mathrm{RQ}>0.667$ (Robinson \& Williams 1999, and references therein).

The respiratory quotients reported here, therefore, are some of the first to be published for Antarctic microplankton and support the use of a mean constant conversion factor from consumption of dissolved oxygen to production of DIC of $\sim 0.9$.

\section{Apportionment of dark community respiration}

As discussed by Arístegui et al. (1996) and Banse (1995), a knowledge of the magnitude and variability of phytoplankton and microbial respiration is required in order to budget microbial carbon flow and estimate the percentage of primary production returned to the atmosphere by top predators.

Measurements of plankton community respiration rates are needed to provide the currently missing constraint of the maximum respiration rate and minimum conversion efficiency of each trophic group. However, a more detailed understanding of the transfer of carbon through the complex microbial food web would be achieved if community respiration could be apportioned between the major components of the microbial community (i.e. algae, bacteria and protozooplankton).

Algal respiration is thought to account for the majority of community respiration in eutrophic ecosystems such as Antarctic coastal waters (Lancelot et al. 1991), a view supported by strong correlations between respiratory electron transport activity of microplankton $(<200 \mu \mathrm{m})$ and phytoplankton biomass and productivity (Estrada et al. 1992, Martinez \& Estrada 1992, Arístegui \& Montero 1995). In the present study, no significant correlation was found between community respiration and either chlorophyll a or photosynthesis. Furthermore, the limited set of size fractionated DCR $\left[\mathrm{O}_{2}\right]$ measurements (Table 4) suggests that, while on average more than $95 \%$ of the ${ }^{14} \mathrm{C}$ incorporation was attributable to the $>2 \mu \mathrm{m}$ fraction (Table 2), on 19 January 1994 more than $90 \%$ of the DCR[O $\mathrm{O}_{2}$ w was associated with the $<2 \mu \mathrm{m}$ fraction and on 14 February 1994 more than $50 \%$ of the $\mathrm{DCR}\left[\mathrm{O}_{2}\right]$ was associated with the $<0.8 \mu \mathrm{m}$ fraction. The uncoupling or time lag between peaks of autotrophic and heterotrophic activity is also clearly seen in Fig. 3. Thus, the attribution of the major portion of DCR to the activity of autotrophs in this particular situation is an oversimplification.

The concomitant measurement of bacterial production and biomass, nanoflagellate bacterivory and biomass (Leakey et al. 1996), dinoflagellate herbivory and biomass (Archer et al. 1996a) and ciliate herbivory and biomass (J. Grey \& R. J. G. Leakey unpubl.) enables a preliminary apportionment of dark community respiration to trophic group (Table 5). The percentage of community respiration attributable to bacteria was calculated assuming ${ }^{3} \mathrm{H}$-thymidine incorporation measured gross bacterial production and using a growth efficiency of 0.4 (Bjørnsen \& Kuparinen 1991). The respiration rate of the heterotrophic nanoflagellate and dinoflagellate communities could be calculated by 2 methods. Measurements of nanoflagellate bacterivory (Leakey et al. 1996) and dinoflagellate herbivory (Archer et al. 1996a) were converted to respiration rates assuming a growth efficiency of 0.4 and a negligible excretion rate. Respiration rates were also derived from taxon specific cell volume data, a relationship normalised to $20^{\circ} \mathrm{C}$ between cell volume and oxygen consumption rate (Caron et al. 1990), a $Q_{10}$ of 2 and an $R Q$ of 0.88 . Ciliate respiration rate was similarly derived from ciliate biomass and abundance data, using a conversion factor of $0.19 \mathrm{pg} \mathrm{C} \mu \mathrm{m}^{-3}$.

Summation of these estimates of bacterial, ciliate, nano- and dinoflagellate respiration suggests that the

Table 4. Size-fractionated dark community respiration ( $\mathrm{mmol} \mathrm{O}_{2} \mathrm{~m}^{-3} \mathrm{~d}^{-1} \pm \mathrm{SE}$ ). nd: not determined

\begin{tabular}{|c|c|c|c|c|c|c|}
\hline \multirow[t]{2}{*}{ Date } & \multicolumn{6}{|c|}{ Oxygen flux (mmol $\mathrm{O}_{2} \mathrm{~m}^{-3} \mathrm{~d}^{-1} \pm \mathrm{SE}$ ) } \\
\hline & Community & $<200 \mu \mathrm{m}$ & $<100 \mu \mathrm{m}$ & $<18 \mu \mathrm{m}$ & $<2 \mu \mathrm{m}$ & $<0.8 \mu \mathrm{m}$ \\
\hline $19 \operatorname{Jan} 94$ & $4.9 \pm 2.1$ & nd & nd & $3.8 \pm 1.3$ & $4.6 \pm 0.3$ & nd \\
\hline $24 \operatorname{Jan} 94$ & $11.1 \pm 2.7$ & $10.2 \pm 0.7$ & $9.4 \pm 0.6$ & nd & nd & nd \\
\hline 14 Feb 94 & $10.5 \pm 1.6$ & nd & nd & nd & nd & $5.6 \pm 1.0$ \\
\hline
\end{tabular}


Table 5. Estimate of the percentage of dark community respiration (DCR; mmol C m${ }^{-3} \mathrm{~d}^{-1}$ ) attributable to bacterial, microzooplankton and algal respiration. When necessary, data is linearly interpolated to the productivity sampling dates. nd $=$ not determined

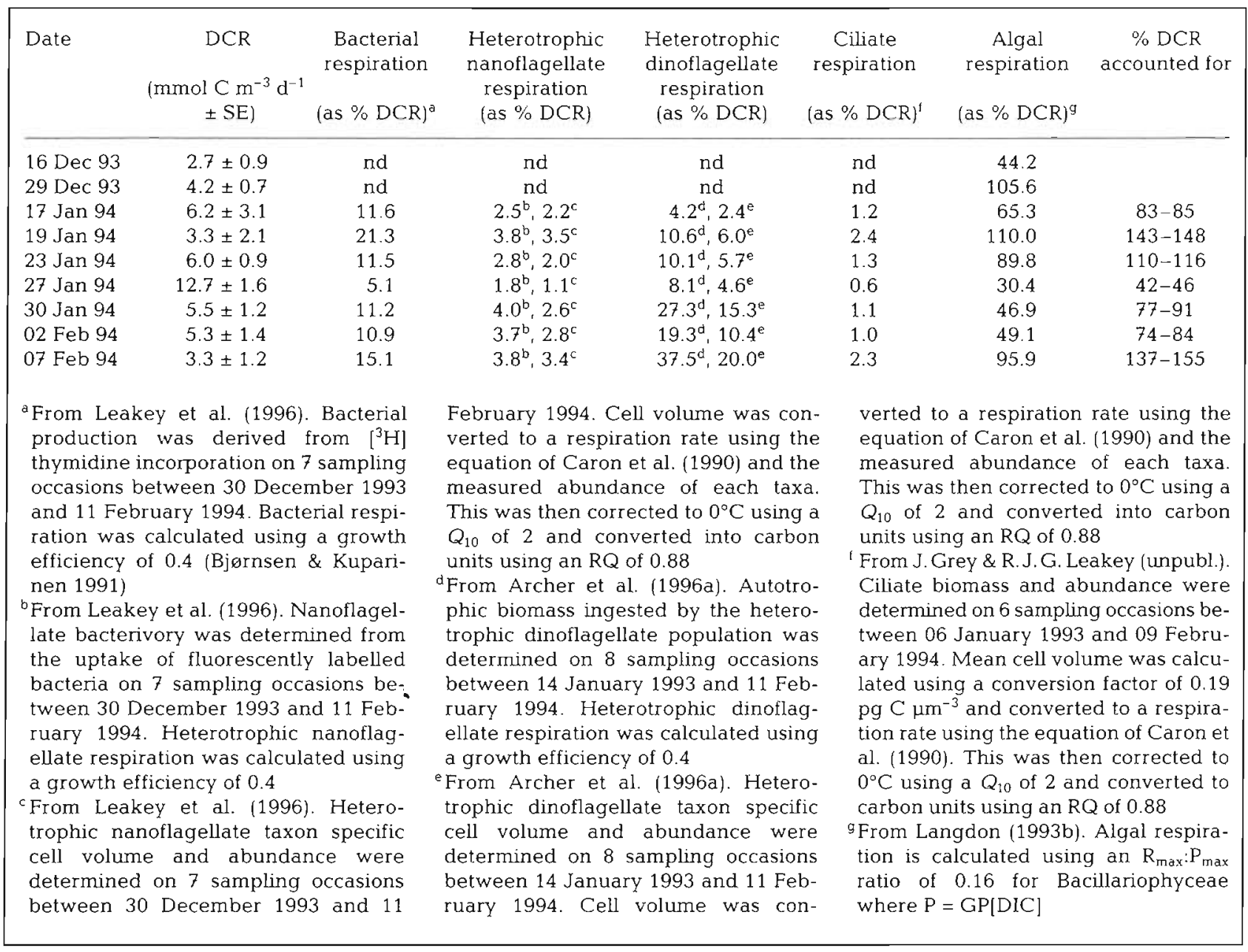

activity of these heterotrophs can account for 15 to $58 \%$ of the measured DCR, confirming that a consistent apportionment of the majority of community respiration to algal respiration is an oversimplification. The 42 to $85 \%$ of measured DCR not accounted for by this budget of heterotrophic groups will in part be due to algal respiration. Unfortunately we have no independent measure of algal respiration to close the budget. Calculating the percentage of community respiration attributable to the algal population using the $R_{\max }: P_{\max }$ ratio of 0.16 for Bacillariophyceae (Langdon 1993b) gives a range for algal respiration of 30 to $110 \%$ of the measured DCR (Table 5). Summation of the estimates of heterotrophic and algal respiration gives a range from 42 to $155 \%$ of measured DCR, with no particular trend of under- or overestimate. For example, an underestimate might be expected if $P$ was significantly lower than $\mathrm{P}_{\max }$ (causing the $\mathrm{R}_{\max }: \mathrm{P}_{\text {max }}$ to be an underestimate). The greatest underestimate of measured DCR occurs just after the peak in diatom-dominated algal biomass and photosynthesis, so an argument could be made for significant self-shading and thus light limitation of photosynthesis on this day. However, it is difficult to see how this would have occurred on 27 January 1994 and not on 23 January 1994, when the chlorophyll a biomass was higher. On 7 February 1994 as well, when GP and chlorophyll a concentration decreased abruptly, potentially due to wind mixing and sediment resuspension, measured DCR was substantially over-accounted for rather than underestimated, which would have been the case if light limitation had been involved. Some of the underestimate of measured DCR just after the diatom peak may be due to unaccounted for microheterotrophs such as microsized metazoans and other protozoa.

Bearing in mind the various assumptions involved, the interpolation of measurements onto concomitant sampling dates and the use of generalised conversion factors, perhaps this accounting (to within 50\% of measured DCR) is as good as one might expect, and is 
certainly no worse than the commonly accepted estimates of ${ }^{14} \mathrm{C}$ photosynthesis and ${ }^{3} \mathrm{H}$-thymidine bacterial production. The detailed analysis of the activity of the heterotrophic community, as described here, is rare. Thus, despite these difficulties in accounting, the apportionment of respiration in this way is a very useful exercise in constraining the various measurements, and highlighting areas where our knowledge is lacking. The agreement between the 2 independent estimates of nanoflagellate respiration is encouraging and the trend of an (almost an order of magnitude) increase in the contribution of dinoflagellate respiration to community respiration after the chlorophyll a peak would seem logical.

This analysis of the activity of the heterotrophic community, together with the estimate of autotrophic production via 3 independent methods, suggests the succession of polar plankton communities to be at least as complex as that in lower latitudes.

Acknowledgements. We are indebted to all at Davis during the summer season 1993/1994 for providing a friendly working environment, particularly to Warren Miller, Peter Sprunk, John Hinton and Rex Davies for boat handling and maintenance. Many thanks to the rest of the 'Pommy Bio' team for their fantastic team spirit and scientific support. Jon Grey, Ray Leakey and John Gibson kindly allowed use of their unpublished data, and Mark Mackenzie helped with locating meteorological data. We acknowledge the considerable logistical and scientific support of the Australian Antarctic Division, in particular that of Harvey Marchant and Andrew Davidson. Thanks to Tony Fogg, Julian Priddle and Dominique Lefèvre for helpful comments on an earlier draft of this manuscript and to the 2 anonymous reviewers who helped in its final throes of restructuring. C.R. was supported on a NERC Antarctic Special Topic GST/02/651 awarded to P.J.le B.W. and S.A. on a NERC Antarctic Special Topic GST/02/656 awarded to M. A. Sleigh, P.H. Burkill and R. J.G. Leakey. During the preparation of this manuscript C.R. was funded by a NERC Advanced Research Fellowship (GT5/96/8/MS), S.A. was funded by DERA (DERA/SSES/C21.10.2) and P. J.leB.W. was in receipt of a Higher Education Funding Council for Wales Professorship.

\section{LITERATURE CITED}

Archer SD, Leakey RJG, Burkill PH, Sleigh MA (1996a) Microbial dynamics in coastal waters of East Antarctica: herbivory by heterotrophic dinoflagellates. Mar Ecol Prog Ser 139:239-255

Archer SD, Leakey RJG, Burkill PH, Sleigh MA, Appleby CJ (1996b) Microbial ecology of sea ice at a coastal Antarctic site: community composition, biomass and temporal change. Mar Ecol Prog Ser 135: 179-195

Arístegui J, Montero MF (1995) Plankton community respiration in Bransfield Strait (Antarctic Ocean) during austral spring. J Plankton Res 17:1647-1659

Arístegui J, Montero MF, Ballesteros S, Basterretxea G, van Lenning $K$ (1996) Planktonic primary production and microbial respiration measured by ${ }^{14} \mathrm{C}$ assimilation and dissolved oxygen changes in coastal waters of the Antarc- tic Peninsula during austral summer: implications for carbon flux studies. Mar Ecol Prog Ser 132:191--201

Arrigo KR, McClain CR (1994) Spring phytoplankton production in the western Ross Sea. Science 266:261-263

Banse K (1995) Antarctic marine top predators revisited: homeotherms do not leak much $\mathrm{CO}_{2}$ to the air. Polar Biol 15:93-104

Benson BB, Krause D Jr (1984) The concentration and isotopic fractionation of oxygen dissolved in freshwater and seawater in equilibrium with the atmosphere. Limnol Oceanogr 29:620-632

Billen G, Becquevort S (1991) Phytoplankton-bacteria relationship in the Antarctic marine ecosystem. ProMare Symposium on Marine Arctic Ecology, Trondheim.

Billen G, Fontigny A (1987) Dynamics of a Phaeocystis-dominated spring bloom in Belgian coastal waters II. Bacterioplankton dynamics. Mar Ecol Prog Ser 37:249-257

Bjørnsen PK, Kuparinen J (1991) Determination of bacterioplankton biomass, net production and growth efficiency in the Southern Ocean. Mar Ecol Prog Ser 71:185-194

Blight SP (1996) Microbial metabolism and temperature; comparative studies in the Southern Ocean and a temperate coastal ecosystem. PhD thesis, University of Wales, Bangor

Blight SP, Bentley TL, Lefèvre D, Robinson C, Rodrigues R, Rowlands J, Williams PJleB (1995) Phasing of autotrophic and heterotrophic planktonic metabolism in a temperate coastal ecosystem. Mar Ecol Prog Ser 128:61-75

Boyd PW, Robinson C, Savidge GJ, Williams PJleB (1995) Water column and sea ice primary production during austral spring in the Bellingshausen Sea. Deep-Sea Res II 42:1177-1200

Caron DA, Goldman JC, Fenchel T (1990) Protozoan respiration and metabolism. In: Capriulo GM (ed) Ecology of marine protozoa. Oxford University Press, Oxford, p 307-322

Clarke A, Leakey RJG (1996) The seasonal cycle of phytoplankton, macronutrients, and the microbial community in a nearshore Antarctic marine ecosystem. Limnol Oceanogr 41:1281-1294

Codispoti LA, Friederich GE, Sakamoto CM, Gordon LI (1991) Nutrient cycling and primary production in the marine systems of the Arctic and Antarctic. J Mar Syst 2:359-384

Davidson AT, Marchant HJ (1987) Binding of manganese by Antarctic Phaeocystis pouchetii and the role of bacteria in its release. Mar Biol 95:481-487

Davidson AT, Marchant HJ (1992) Protist abundance and carbon concentration during a Phaeocystis-dominated bloom at an Antarctic coastal site. Polar Biol 12: 387-395

Department of Energy US (DOE) (1994) Handbook of methods for the analysis of the various parameters of the carbon dioxide system in seawater, version 2. Dickson AG, Goyet $C$ (eds) Oak Ridge National Laboratory/Carbon Dioxide Information Analysis Centre (ORNL/CDIAC) 74

Estrada M, Martinez R, Mathot S (1992) Respiratory electron transport activity in plankton of the Weddell and Scotia Seas during late spring - early summer: relationships with other biological parameters. Polar Biol 12:35-42

Gibson JAE, Swadling KM, Burton HR (1997) Interannual variation in dominant phytoplankton species and biomass near Davis Station, East Antarctica. Proc NIPR Symp Polar Biol 10:77-89

Holm-Hansen O, Mitchell BG (1991) Spatial and temporal distribution of phytoplankton and primary production in the western Bransfield Strait region. Deep-Sea Res 38: $961-980$

Irwin B (1991) Coulometric measurement of primary production, with comparison against dissolved oxygen and ${ }^{14} \mathrm{C}$ methods in a seasonal study. Mar Ecol Prog Ser 71:97-102 
JGOFS (1990) Science plan. JGOFS report no. 5. Scientific Committee on Oceanographic Research, Halifax, Canada. ISSN 1016-7331

Johnson KM, Sieburth JMcN, Williams PJleB, Brandstrom L (1987) Coulometric total carbon dioxide analysis for marine studies: automation and calibration. Mar Chem 21:117-133

Joint IR, Pomroy AJ (1983) Production of picoplankton and small nanoplankton in the Celtic Sea. Mar Biol 77:19-27

Karl DM (1993) Microbial processes in the Southern Oceans. In: Friedmann EI (ed) Antarctic microbiology. Wiley-Liss, Inc, New York, p 1-63

Lancelot C, Billen G, Veth C, Becquevort S, Mathot S (1991) Modelling carbon cycling through phytoplankton and microbes in the Scotia-Weddell Sea area during sea ice retreat. Mar Chem 35:305-324

Langdon C (1992) In situ sampler-incubator for simultaneous biological rate measurements via tracers and net chemical change. Limnol Oceanogr 37:1823-1830

Langdon C (1993a) Community respiration measurements using a pulsed oxygen electrode. In: Kemp PF, Sherr BF, Sherr EB, Cole JJ (eds) Handbook of methods in aquatic microbial ecology. Lewis Publishers, Boca Raton, p 447-453

Langdon $C$ (1993b) The significance of respiration in production measurements based on oxygen. ICES Mar Sci Symp $197: 69-78$

Langdon C, Marra J, Knudson C(1995) Measurements of net and gross oxygen production, dark oxygen respiration and ${ }^{14} \mathrm{C}$ assimilation at the ML-ML site in the NE Atlantic Ocean. J Geophys Res 100:6645-6653

Laws EA (1991) Photosynthetic quotients, new production and net community production in the open sea. Deep-Sea Res 38:143-167

Leakey RJG, Archer SD, Grey J (1996) Microbial dynamics in coastal waters of East Antarctica: bacterial production and nanoflagellate bacterivory. Mar Ecol Prog Ser 142:3-17

Li WKW, Goldman JC (1981) Problems in estimating growth rates of marine phytoplankton from short-term. ${ }^{14} \mathrm{C}$ assays Microb Ecol 7:113-121

Li WKW, Harrison WG (1982) Carbon flow into the end products of photosynthesis in short and long incubations of a natural phytoplankton population. Mar Biol 72:175-182

Martinez R, Estrada M (1992) Respiratory electron transport activity of microplankton in the Weddell Sea during early spring: influence of the ice cover and the ice edge. Polar Biol 12:275-282

Moline MA, Prézelin BB (1997) High-resolution time-series data for $1991 / 1992$ primary production and related parameters at a Palmer LTER coastal site: implications for modeling carbon fixation in the Southern Ocean. Polar Biol 17. $39-53$

Perrin RA, Lu P, Marchant HJ (1987) Sedsondl variation in marine phytoplankton and ice algae at a shallow antarctic coastal site. Hydrobiologia 146:33-46

Pomeroy LR, Deibel D (1986) Temperature regulation of bacterial activity during the spring bloom in Newfoundland coastal waters. Science 233:359-361

Pomeroy LR, Sheldon JE, Sheldon WMI Jr (1994) Changes in bacterial numbers and leucine assimilation during estimations of microbial respiratory rates in seawater by the

Editorial responsibility: Otto Kinne (Editor).

Oldendorf/Luhe, Germany precision Winkler method. Appl Environ Microbiol 60 $328-332$

Richardson K, Samuelson G, Hällgren JE (1984) The relationship between photosynthesis measured by ${ }^{14} \mathrm{C}$ incorporation and by uptake of total dissolved inorganic carbon in unicellular algae. J Exp Mar Biol Ecol 81:241-250

Robinson C, Williams PJleB (1991) Development and assessment of an analytical system for the accurate and continual measurement of total dissolved inorganic carbon. Mar Chem 34:157-175

Robinson C, Williams PJleB (1993) Temperature and AntarCtic plankton community respiration. J Plankton Res 15 $1035-1051$

Robinson C, Williams PJleB (1999) Plankton net community production and dark respiration in the Arabian Sea during September 1994. Deep-Sea Res 46:745-766

Robinson C, Archer SD, Grey J, Leakey RJG, Gibson JAE, Williams PJleB (1996) Factors controlling the magnitude and variability of net community production in Antarctic nearshore waters. EOS $76(3): 188$

Ryther JH (1956) The measurement of primary production. Limnol Oceanogr 1:72-84

Sakshaug E, Holm-Hansen O (1986) Photoadaptation in Antarctic phytoplankton: variations in growth rate, chemical composition and $P$ versus $I$ curves. J Plankton Res $8: 459-473$

Savidge G, Harbour D, Gilpin GC, Boyd PW (1995) Phytoplankton distributions and production in the Bellingshausen Sea, austral spring 1992. Deep-Sea Res II 42: $1201-1224$

Steemann Nielsen E (1952) The use of radioactive carbon $\left({ }^{14} \mathrm{C}\right)$ for measuring organic production in the sea. J Cons Int Explor Mer 18:117-140

Steemann Nielsen E, Hansen V Kr (1959) Measurements with the carbon-14 technique of the respiration rates in natural populations of phytoplankton. Deep-Sea Res 5:222-233

Strickland JDH, Parsons TR (1972) A practical handbook of seawater analysis. Bull Fish Res Bd Can 167:1-310

Whitaker TM (1982) Primary production of phytoplankton off Signy Island, South Orkneys, the Antarctic. Proc R Soc Lond B 214:169-189

Williams PJleB (1981) Microbial contribution to overall marine plankton metabolism: direct measurements of respiration. Oceanol Acta 4:359-364

Williams PJleB (1993) Chemical and tracer methods of measuring plankton production. ICES Mar Sci Symp 197: $20-36$

WiJliams PJleB, Jenkinson NW (1982) A transportable microprocessor-controlled precise Winkler titration suitable for field station and shipboard use. Limnol Oceanogr 27: 576-584

Williams FJleB, Robertson JE (1991) Overall planktonic oxygen and carbon dioxide metabolisms: the problem of reconciling observations and calculations of photosynthetic quotients. J Plankton Res 13:153-169

Williams PJleB, Robinson C, Sondergaard M, Jespersen AM, Bentley TL, Lefèvre D, Richardson K, Riemann B (1996) Algal ${ }^{14} \mathrm{C}$ and total carbon metabolisms. 2. Experimental observations with the diatom Skeletonema costatum. J Plankton Res 18:1961-1974

Submitted: March 19, 1998; Accepted: December 9, 1998 Proofs received from author(s): April 12, 1999 